\title{
АНАЛІЗ СТАНУ КРОВОТОКУ НА БАЗІ ЛАЗЕРНОГО ДОППЛЕРІВСЬКОГО AHEMOMETPA
}

\author{
Богомолов М.Ф., дои, к.т.н. \\ nbogom@yahoo.com \\ Tроц A.A., дои, к.т.н. \\ adamtroc@ukr.net \\ Чапля Д.В., студент \\ dmitrochaplya@gmail.com \\ Кафедра біомедичної інженерії \\ Національний технічний університет України \\ «Київський політехнічний інститут імені Ігоря Сікорського»
}

\begin{abstract}
Реферат - У багатофазних рідких середовищах для ефективного безконтактного вимірювання швидкості потоку доиільно використовувати лазерну допплерівську анемометрію.Цей метод передбачає наявність в речовині світлорозсіювальних частинок. Лазерна допплерівська анемометрія (також відома як лазерна допплерівська велосиметрія)- ие неінвазивний метод вимірювання швидкості потоку, який дозволяє проводити вимірювання в трьох просторових координатах, визначати швидкість потоку для багатофазних течій. Також ией метод завдяки реєстрачії допплерівського зміщення надає можливість оцінки ступеня турбулентності течії.У даній статті пропонується використовувати допплерівську анемометрію для оцінки реологічних характеристик крові людини в умовах in vitro, отримання значень швидкості переходу течії крові в турбулентний режим, щуо дасть змогу в подальшому прискорити процес діагностики сериево-судинної системи людини.В роботі представлено схему лабораторної установки та запропонована методика дослідження кровотоку.
\end{abstract}

Ключові слова: Двофазна течія, лазер, допплерівський анемометр, оптичний метод.

\section{I. Вступ}

Одними 3 важливих параметрів кровотоку людини є такі показники як: в'язкість крові, коефіцієнт тертя, та характер течії крові. Для людини більш характерний ламінарний рух крові, адже в нормі турбулентні течії можуть утворюватися в місцях розгалуження судин. Але, на нерозгалужених ділянках турбулентна течія на може вказувати на раптове звуження судинного просвіту та негативно впливати на серцево-судинну систему. Останнім часом бурхливо розвиваються методи оптичної діагностики багатофазних середовищ. Одними 3 приладів, що дозволяє дослідити такі середовища, $\epsilon$ лазерний допплерівський анемометр 3 диференціальною схемою i лазерний решітчатий анемометр.

Принципова різниця між ними полягає в тому, що просторова решітка-модулятор у першому приладі формується за рахунок інтерференції двох когерентних пучків лазера. В другому приладі проектується в потік оптичною системою. Звідси випливає, що решітчатий анемометр не вимагає когерентного джерела світла, а отже, цей прилад більш простий у реалізації оптичної схеми. Однак у зв'язку з тим, що інтерференція двох гаусових пучків когерентного світла дає решітки 3 синусоїдальним просторовим розподілом освітленості, ЛДА має більш «чистий» сигнал 3 малим вмістом сторонніх гармонік. Головною метою цієї статті $\epsilon$ розробка лабораторної установки для експресного дослідження параметрів в'язкості крові та фіксація швидкості потоку, при якому окремі фази переходять в турбулентний режим.

\section{II. МЕТА ДОСЛІДЖЕННЯ}

Наразі існує багато робіт присвячених гемодинаміці та реологічним властивостям крові. У тому числі фундаментальні роботи таких авторів як: Pinsky M i соавт.[1] a також статті Tu J., Inthavong K., Wong K.[2], в яких розглянуто клінічні аспекти медичної діагностики і теоретичні методи моделювання системи кровотоку людини. Одним з важливих досліджень у цій сфері $є$ 
стаття іранських вчених М. Jahangiri, M. Saghafian i M. R. Sadeghi[3], де було створено та описано модель стенозованої артерії, а також вказувалися розрахунки параметрів кровотоку, які були визначені за допомогою методу кінцевих різниць. Подана робота доводить, що при $~ 80 \%$ стенозі артерії можливе виникнення турбулентного потоку з подальшим його розповсюдженням прямолінійними ділянкам.

Головними завданнями нашої роботи є дослідження параметрів переходу окремих фаз крові у турбулентний режим, а також аналіз методів оптичної діагностики двофазних середовищ, що використовує лазерні допплерівські анемометри для вимірювань криволінійних поверхонь на КВМ, та підвищення швидкодії і точності вимірювання контактним методом 3 врахуванням похибок вимірювання та застосування програмного забезпечення.

\section{TEXHIYHI \\ ХАРАКТЕРИСТИКИ ЛАЗЕРНОГО ДОППЛЕРІВСЬКОГО AHEMOMETPA}

В даній роботі доцільно використовувати лазерний допплерівський анемометр, оскільки він має ряд суттєвих переваг за рахунок своєї конструкції. Оптичну схему ЛДА, яку використовує пряме розсіювання світла, представлено на Рис.1. Промінь лазера 1 розщеплюється у вузлі 2 на два пучка однакової інтенсивності, які сходяться під кутом $\theta$ в точці каналу $A$, де уздовж осі $x$ рухаються світлорозсіюючі частинки зі швидкістю $c_{k}$. Світлорозсіюючі частинки уздовж осі $y$ збираються об'єктивом 3 на поверхні катода фотоприймача 5. Діафрагма 4 використовується для зменшення шумів. У точці перетину когерентних пучків $A$ виникає просторова синусоїдальна інтерференційна решітка.
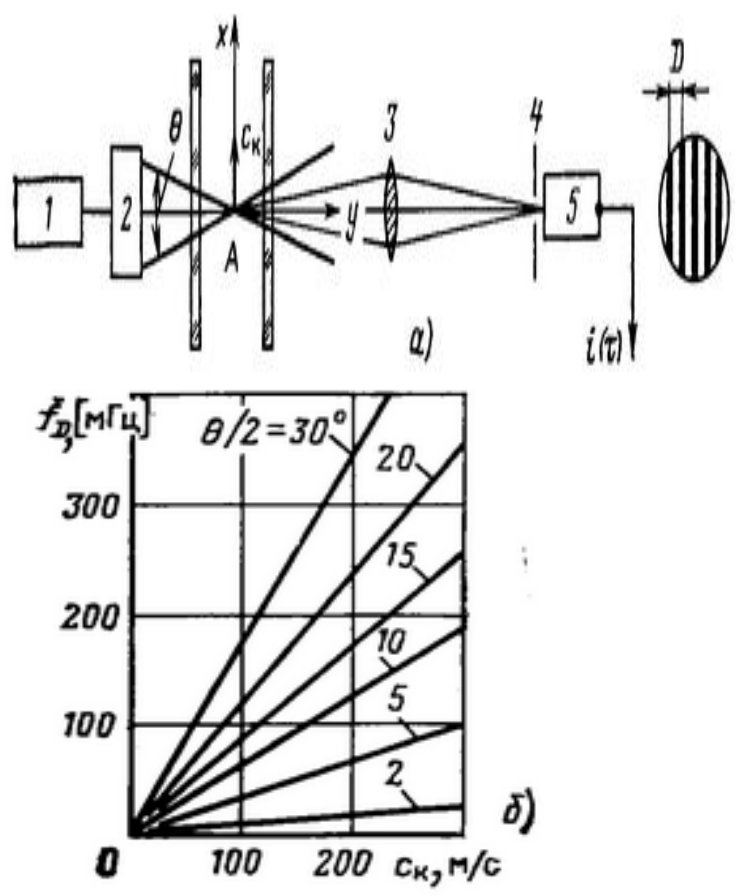

Рис. 1. А) - Схема лазерного допплерівського анемометра, Б) Допплерівський зсув при різних $\theta$ для ЛДА.

Для більш повного розуміння чому доцільніше використовувати саме допплерівський анемометр 3 диференційною схемою наводимо схему ЛРА, та порівняння 3 схемою ЛДА при використанні аналогічних оптичних схем.
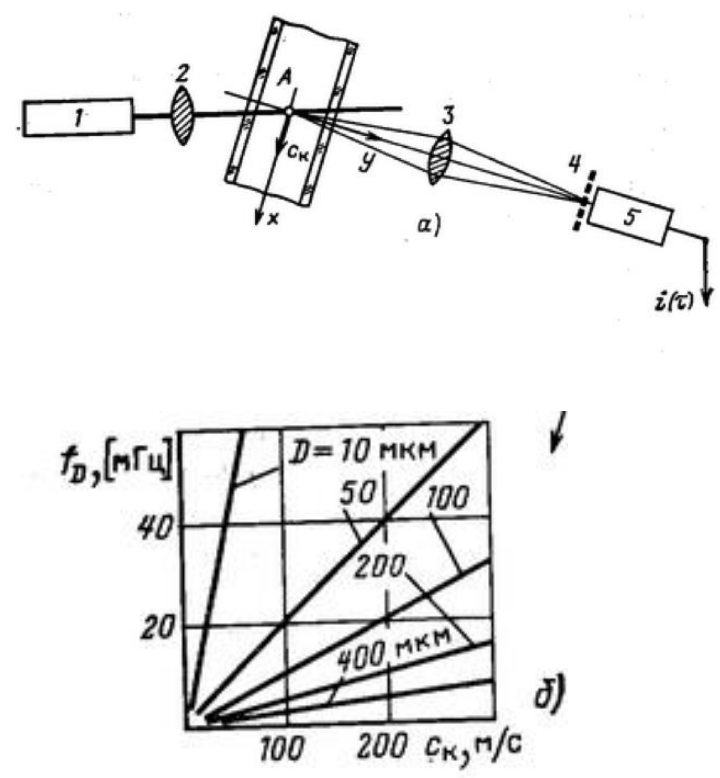

Рис. 2. А) - Схема решітчастого анемометра, Б) - зміни $f_{d}$ в залежності від $c_{k}$. 
У ЛРА зазвичай використовують решітку 3 просторовим розподілом освітленості (пропускання) у вигляді меандру, але сигнал містить вищі гармоніки, тобто менш «чистий». Енергетичний розрахунок для ЛДА і ЛРА показує, що при рівних умовах ЛДА вимагає в 2 рази менш потужне джерело світла, так як при інтерференції пучків в місці максимальної освітленості просторової решітки хвилі світла додаються, тоді як в ЛРА половина потужності джерела зникає - затемнюється просторовою решіткою-модулятором.

Лазерні системи 3 волоконними світловодами успішно вирішують задачу вимірювання швидкостей в оптичних непрозорих середовищах типу крові. Ефект вимірювання швидкості в оптично непрозорому потоці досягається шляхом приміщення світловода (або пучка світловодів) в задану малу локальну область потоку. При чому інформація про швидкість руху частинок береться 3 простору в безпосередній близькості від торця світловода. 3 огляду на досить високу ступінь когерентності лазерного пучка, що пройшов волоконний світловод, можна припустити що можливо, що всі основні схеми ЛДВШ можуть бути реалізовані 3 волоконними світловодами.

Для багатофазних середовищ при вимірюванні швидкості несучої фази необхідно вводити потік світлорозсіюючих частинок. 3 цією метою створюються спеціальні генератори [4]. На основі цієї технології вже існує система для визначення сторонніх включень у паливі, яка підтвердила свою ефективність. Основою нашого дослідження можна вважати існуючу систему BV520, яка призначена для подальшого покращення приладу. Ця система визначає стан потоку (турбулентний, ламінарний), також вимірює середню швидкість частинок у несучій фазі. Також цілком можливе іï застосування для визначення стану артеріального чи венозного кровотоку частотою у 7,5 МГц. Також BV520 застосовується для вимірювання швидкості крові під час відновлення та кровотоку периферичних судин. Найкраща температура для проведення маніпуляцій складає 10-40 ${ }^{\circ} \mathrm{C}$. Екран дисплея має світлодіод з роздільною здатністю 20 bit. Допплерівська частота знаходиться у межах від 100 до 7000 Гц. Характеристика вихідного сигналу: 9В, 1000 мА. Акумулятор продукту - 7,4 В / 900 мАч (літієвий аккумулятор). Окрім якості оптичної системи, ефективність роботи розробленої лабораторної установки визначається якістю переходу ламінарного режиму кровотоку до турбулентного в об’ємі робочої зони аналізатора.

\section{IV. ПРИНЦИПОВА CХЕМА ЛАБОРАТОРНОЇ УСТАНОВКИ}

Запропонована методика дослідження кровотоку, яка грунтується на визначенні «точки переходу» ламінарного режиму до турбулентного для трьох рідин 3 різними величинами в'язкості 3 використанням лазерної діагностики багатофазних потоків рідини. Конструкція дослідної установки (Рис. 3, а.) складається 3: вимірювального об`єму 1 , з`єднаного із об`ємом 3 однією із трьох вимірювальних рідин 4 за допомогою шлангу 7. Для створення потоку рідини 3 необхідною швидкістю циліндр, 3 в якому знаходиться об'єм рідини 1 , оснащений поршнем 2, який навантажується 3 вантажками. У зоні вимірювання, де нанесено нормувальну шкалу 1, розташований лазерний випромінювач $5 \mathrm{i}$ лазерний приймач 6. Початкова і кінцева довжини забезпечують умови створення необхідного режиму потоку на вимірювальній довжині. Дослідна установка додатково оснащена міні відеокамерою, яка з`єднана з комп’ютером.

При вимірювальні об ємів 3 трьома рідинами різної в'язкості, в які введені різні барвники (Рис. 4, а.), вони послідовно встановлюються на стійці 3 лазерною системою i завантажуються однаковим набором вимірювальних вантажів. У цьому випадку мінімальний вантаж створює «точку переходу» ламінарного режиму в турбулентний першої рідини з мінімальною в'язкістю. 

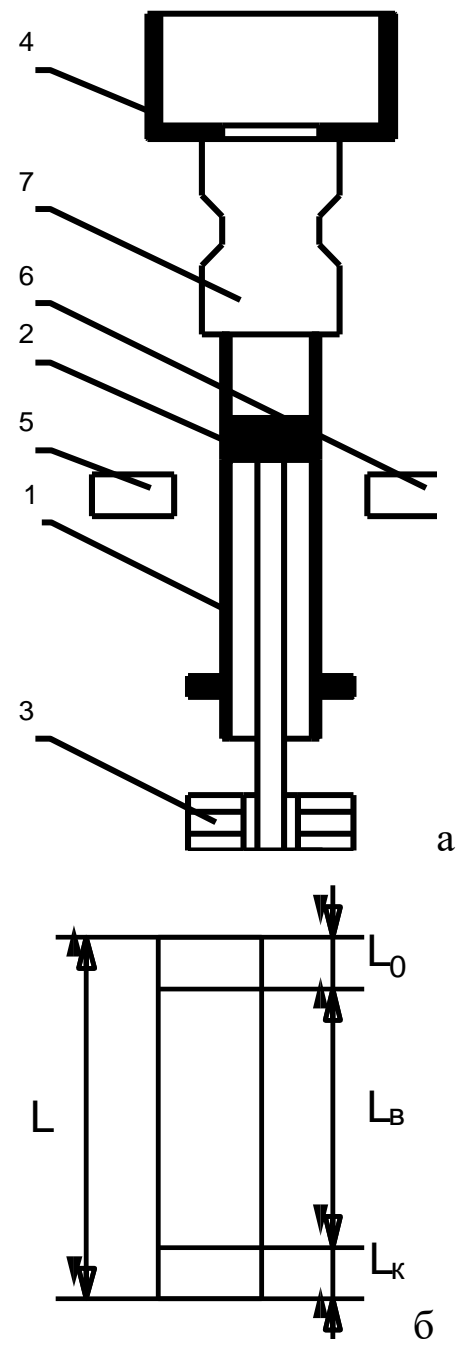

Рис. 3. а-Принципова схема дослідної установки.

б - Схема вимірювального об’єму.

Середній вантаж створює «точку переходу» рідини з середньою в'язкістю. Максимальний вантаж створює «точку переходу» в рідині 3 максимальною в'язкістю. Данні 3 усіх трьох випадків оцифровуються, та вносяться до комп'ютерної моделі. При цьому мінімальна маса вимірювальних вантажив створює турбулентний режим у потоці першої рідини 3 мінімальною в язкістю і забезпечує ламінарні режими у потоках двох інших рідин, середня маса створює турбулентний режим у потоках першої i другої рідин і ламінарний режим у потоці третьої рідини 3 максимальною в язкістю. (Рис. 4, б.).
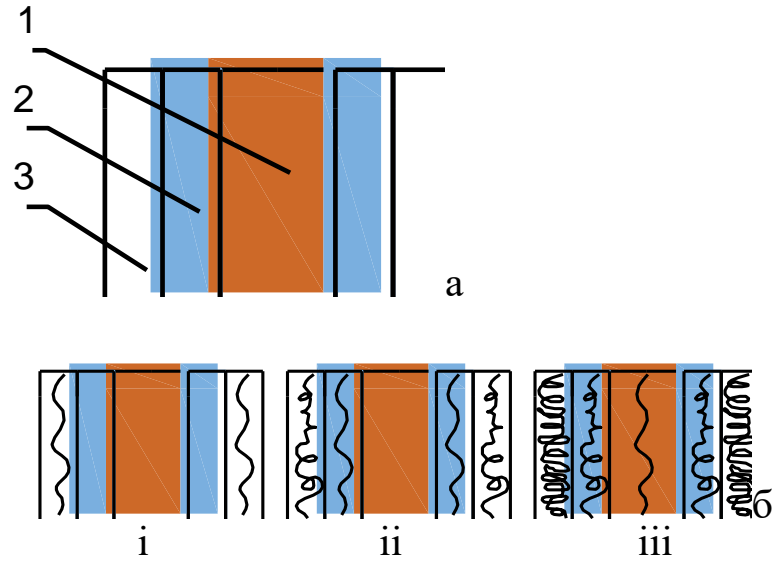

Рис.4. Схема потоків рідини

і-Мінімальна маса

ii - Середня маса

iii - Максимальна маса

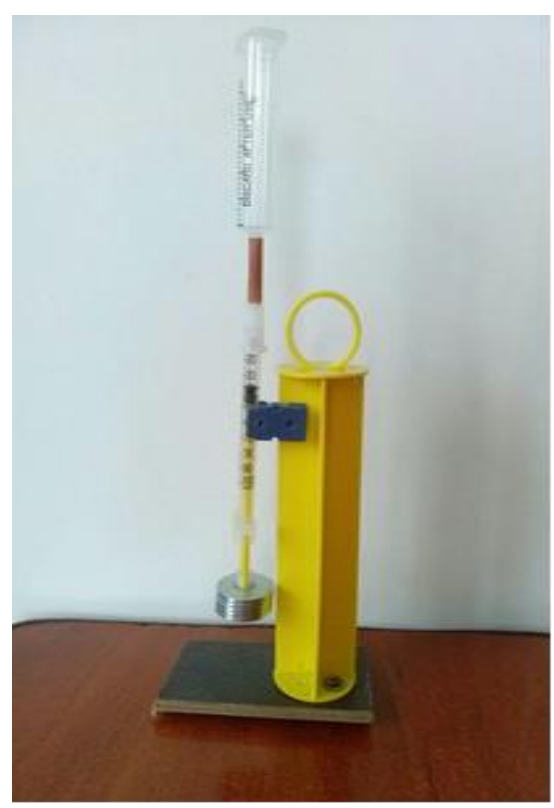

Рис.5. Зовнішній вигляд установки

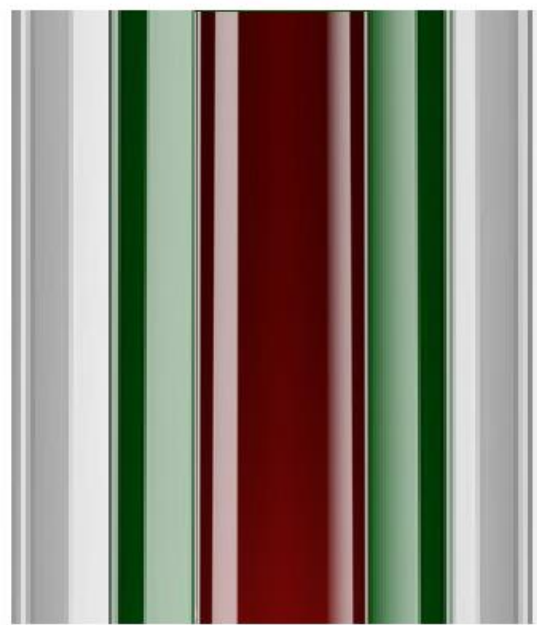

Рис. 6. Комп’ютерна модель трьох потоків. 
Однією 3 ключових проблем, які в подальшому потрібно вирішити, $\epsilon$ підбір реагентів-замінників, які імітували реологічні властивості фракцій крові, оскільки на даному етапі розробки неможливо проводити досліди на людській крові з біоетичних міркувань.

\section{V. РЕОЛОГІЧНІ ВЛАСТИВОСТІ KPOBI}

Для коректної інтерпретації результатів експериментів та побудови комп'ютерної моделі, потрібно розуміти реологічні властивості досліджуваної речовини.

Реологічні властивості крові визначають опір, який повинен бути переборений роботою серця - помпою кровообігу. Патологічні зміни реологічних властивостей крові лежать в основі виникнення й розвитку широкого кола захворювань, особливо це стосується захворювань артерій та вен. Практично всі хірургічні втручання супроводжуються негативними змінами реологічних i коагуляційних властивостей крові, що $\epsilon$ однією 3 найважливіших причин тромбоемболічних ускладнень.

Одним 3 найважливіших реологічних параметрів крові $\epsilon$ в'язкість. В'язкість крові визначається як відношення напруги зсуву до швидкості зсуву, і вимірюється в мПас. Принциповими факторами, що впливають на в'язкість крові, $є$ гематокрит, властивості плазми, агрегація i деформованість клітинних елементів. Враховуючи переважну більшість еритроцитів у порівнянні з лейкоцитами і тромбоцитами, в'язкі властивості крові визначаються в основному червоними клітинами.

Найголовнішим чинником, що визначає в'язкість крові, є об'ємна концентрація еритроцитів (ї зміст і середній об'єм), звана гематокритом. Гематокрит, який визначається 3 проби крові шляхом центрифугування, становить приблизно 0,4
- 0,5 л/л. Плазма є ньютонівською рідиною, iї в'язкість залежить від температури і визначається складом білків крові. Більше всього на в'язкість плазми впливає фібриноген (в'язкість плазми на 20\% вище в'язкості сироватки) і глобуліни (особливо Y-глобуліни). На думку деяких дослідників більш важливим чинником, який веде до зміни в'язкості плазми, $€$ не абсолютна кількість білків, a ї співвідношення: альбумін/глобуліни, альбумін/фібриноген. В'язкість крові збільшується при ії агрегаціï, що визначає неньютонівську поведінку цільної крові [8].

Ламінарний потік це впорядкований рух рідини або газу, при якому рідина (газ) рухається шарами, паралельними до напрямку течії. При цьому перемішування між сусідніми шарами рідини відсутнє.

Ламінарний потік спостерігається за невеликих швидкостей, коли окремі місцеві збурення швидко згасають. Ламінарний потік можна спостерігати на струминах підфарбованої рідини. При збільшенні швидкості потоку ламінарний потік може перейти в турбулентний (вихровий). Умова такого переходу визначається критичним числом Рейнольдса. Кожен конкретний потік має таке критичне число $\mathrm{Re}_{\mathrm{\kappa p}}$, що за будь-якого $\mathrm{Re}<\mathrm{Re}_{\text {кр }}$ ламінарний

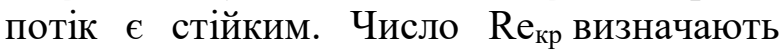
головним чином експериментально. Теоретичне вивчення ламінарних потоків проводять на основі рівнянь Нав'є-Стокса:

$$
\operatorname{Re}=\rho v 1 / \mu,
$$

де $\rho-$ густина, $\mu-$ коефіцієнт динамічної в'язкості, $\mathrm{v}$ - характерна швидкість течії рідини (газу), 1 характерний розмір.

\section{Турбулентним називається}

рух рідини (газу або плазми), що супроводжується утворенням вихорів.

При малих значеннях числа Рейнольдса добуток характерної для течії швидкості плину на характерні розміри 
перешкод малий у порівнянні з в'язкістю. Тому завдяки в'язкості течія зберігає впорядковану структуру. При великих значеннях числа Рейнольдса рух рідини стає турбулентним.

Дослідами Рейнольдса встановлено, що за певних граничних умов у кожному потоці є "точка переходу", яка відповідає зміні одного режиму іншим. Ця точка переходу за Рейнольдсом визначається безрозмірним комплексом - числом Рейнольдса.

Для в'язких (ньютонівських) рідин існує відоме рішення Пуазейля, яке пов'язує об'ємну витрату 3 градієнтом тиску. Формально ламінарна течія Пуазейля існує для будь-яких величин об'ємної витрати, але реально для потоків, витрата яких перевищує деяку критичну величину $(\mathrm{Q} \geq$ Qкр), модель втрачає стійкість. В експериментах виникнення ламінарнотурбулентного переходу визначалося як зі зміни форми профілю швидкості в трубі, так i по відхиленню коефіцієнта гідравлічного опору від розрахункового значення, обчисленого за формулою Гагена-Пуазейля. Слід зазначити, що результати досліджень обома методами співпадають. Експерименти показали, що існує область ламінарної течії, де при введенні в потік збурень утворюється нестійкість ламінарного профілю швидкості, яка, однак, не призводить до виникнення сталого турбулентного руху в трубі, і ламінарний потік відновлюється.

Щодо неньютонівських систем існує досить багато робіт присвячених експериментальним i теоретичним дослідженням течії в круглих трубах рідин, ламінарний течія яких досить повно описується теоретичними залежностями, отриманими на основі в'язко-пластичної моделі Шведова-Бінгама (Bingham). Однак закономірності турбулентного руху течії і ламінарно-турбулентного переходу течій в'язко-пластичних рідин вивчені недостатньо. Експериментальні дані про порушення ламінарного руху течії в'язкопластичних рідин, отримані різними дослідниками, показують, що критичне значення $\operatorname{Re}$ залежить від безрозмірного параметра Хедстрема (Hedstrom)

$$
\mathrm{He}=\frac{\tau_{0} \rho d}{\eta^{2}}
$$

де $\tau 0$ - динамічна напруга зсуву; $\eta$ пластична в'язкість.

Результати досліджень переходу до турбулентності в круглій трубі за допомогою прямого чисельного моделювання впливу вхідних збурень на виникнення турбулентності показали стійкість течії Пуазейля до малих збурень, що узгоджується 3 експериментальними даними.

\section{VI. ОБГОВОРЕННЯ РЕЗУЛЬТАТІВ}

Лазерна допплерівська анемометрія $\epsilon$ інформативним сучасним методом дослідження реологічних властивостей крові та стану крові. Це особливо актуально під час пандемії COVID-19. Застосування лазерної допплерівської анемометрії для створення точних моделей турбулентних течій знадобиться при прогнозуванні наслідків стенозів судин та в подальшому дасть можливість лікарям більш точно оцінювати ризики. Також розвиток цього напрямку дасть змогу розробити більш експресні методи діагностики серцевосудинної системи. 


\section{ПЕРЕЛІК ПОСИЛАНЬ}

1. Pinsky M. Hemodynamic Monitoring / M. Pinsky, J. Teboul, J. Vincent., 2019.

2. Tu J. Computational Hemodynamics - Theory, Modelling and Applications / J. Tu, K. Inthavong, K. Wong..

3. Numerical Study of Turbulent Pulsatile Blood Flow through Stenosed Artery Using Fluid-Solid Interaction [Електронний ресурс] - Режим доступу до ресурсу: https://www.hindawi.com/journals/cmmm/2015/51561 $3 /$.

4.Применение лазерной анемометри в диагностике двухфазных течений [Електронний ресурс]. - 2012. - Режим доступу до ресурса: https://mashxxl.info/page/109189152248092185116080020093035 094190172028077/.
5. Спектрофотометрические приборы для оценки характеристик кровотока [Електронний ресурс]. 2014. - Режим доступу до ресурса: http://ilab.xmedtest.net/?q=node/6106.

6. Флуориметр с многоканальной системой возбуждения на светодиодах [Електронний ресурс]. - 2018. - Режим доступу до ресурса: https://edrid.ru/rid/218.016.4d4b.html.

7. Левицький Б.Ф., Лещій Н.П. Гідравліка. Загальний курс - Львів: Світ, 1994.-264c.

8. Нікітчук Т. М. ДОСЛІДЖЕННЯ МОЖЛИВОСТІ ВИЗНАЧЕННЯ РЕОЛОГІЧНИХ ВЛАСТИВОСТЕЙ КРОВІ ЗА ПАРАМЕТРАМИ ПУЛЬСОВОЇ ХВИЛІ [Електронний ресурс] / Т. М. Нікітчук, В. В. Виниченко - Режим доступу до ресурсу: https://conf.ztu.edu.ua/wpcontent/uploads/2016/07/119.pdf. 


\section{АНАЛИЗ СОСТОЯНИЯ КРОВОТОКА НА БАЗЕ ЛАЗЕРНОГО ДОППЛЕРОВСБКОГО АНЕМОМЕТРА}

Богомолов М.Ф., дои, к.т.н. nbogom@yahoo.com

Троц A.A., дои, к.т.н. adamtroc@ukr.net

Чапля Д.В., студент dmitrochaplya@gmail.com

Кафедра биомедицинской инженерии Национальный технический университет Украины «Киевский политехнический институт имени Игоря Сикорского»

Реферат - в многофазных жидких средах, для эффективного бесконтактного измерения скорости потока, иелесообразно использовать лазерную допплеровскую анемометрию.

Этот метод предполагает наличие в веществе светорассеивающие частии.

Лазерная допплеровская анемометрия (также известная как лазерная допплеровская велосиметрия) - это неинвазивный метод измерения скорости потока, который позволяет проводить измерения в трех пространственных координатах, измерения скорости потока для многофазных течений, а также, дает возможность оценки степени турбулентности течения благодаря регистрачии допплеровского смещения.

В данной статье предлагается использовать этот метод для оценки реологических характеристик крови человека в условия in vitro, также провести получение значений скорости перехода тока крови в турбулентный режим, что позволит в дальнейтем ускорить процесс диагностики сердечно-сосудистой системы человека.

В работе представлена схема лабораторной установки и методика исследования кровотока.

Ключевые слова: Двухфазная течение, лазер, доплеровский анемометр, оптический метод. 


\title{
ANALYSIS OF BLOOD FLOW STATUS BASED ON LASER DOPPLER ANEMOMETER
}

Bogomolov M. F., Associate Professor, Ph.D.. nbogom@yahoo.com

Trots A.A., Associate Professor, Ph.D. adamtroc@ukr.net

Chaplya D.V., student dmitrochaplya@gmail.com

Department of Biomedical Engineering National Technical University of Ukraine "Igor Sikorsky Kyiv Polytechnic Institute" Kiev, Ukraine

\begin{abstract}
Doppler anemometry.

This method involves the presence of light-scattering particles in the substance.

Laser Doppler anemometry is a non-invasive method of measuring flow velocity that allows measurements in three spatial coordinates, flow velocity measurement for multiphase flows, and the ability to estimate the degree of flow turbulence by Doppler recording.

This article proposes to use this method to assess the rheological characteristics of human blood in vitro, to obtain values of the rate of transition of blood flow to turbulent mode, which will further accelerate the diagnosis of the human cardiovascular system.

The scheme of the laboratory installation is presented in the work, the technique of research of a blood-groove is offered.

Keywords: Two-phase flow, laser, Doppler anemometer, optical method.
\end{abstract}

